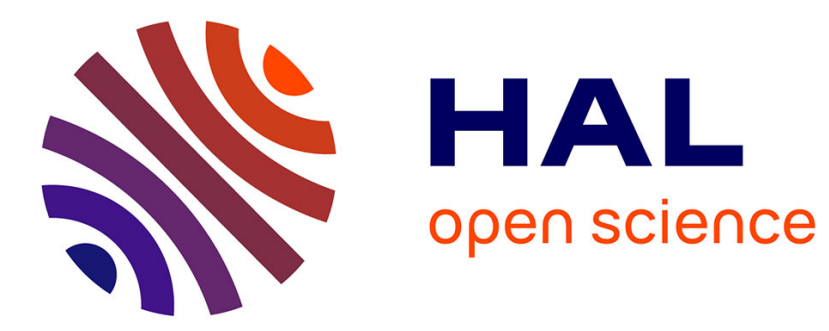

\title{
A new species of larval Leptus (Parasitengona: Erythraeidae) and new records of larval Erythraeidae parasitizing Orthoptera from French Guiana
}

\author{
J.G. Mayoral, P. Barranco
}

\section{- To cite this version:}

J.G. Mayoral, P. Barranco. A new species of larval Leptus (Parasitengona: Erythraeidae) and new records of larval Erythraeidae parasitizing Orthoptera from French Guiana. Acarologia, 2011, 51 (4), pp.411-417. 10.1051/acarologia/20112023 . hal-01600287

\section{HAL Id: hal-01600287 \\ https://hal.science/hal-01600287}

Submitted on 2 Oct 2017

HAL is a multi-disciplinary open access archive for the deposit and dissemination of scientific research documents, whether they are published or not. The documents may come from teaching and research institutions in France or abroad, or from public or private research centers.
L'archive ouverte pluridisciplinaire HAL, est destinée au dépôt et à la diffusion de documents scientifiques de niveau recherche, publiés ou non, émanant des établissements d'enseignement et de recherche français ou étrangers, des laboratoires publics ou privés.

\section{(ㅇ)(1) $\$$}

Distributed under a Creative Commons Attribution - NonCommercial - NoDerivatives| 4.0 




\section{ACAROLOGIA}

A quarterly journal of acarology, since 1959

Publishing on all aspects of the Acari

All information:

http://www1.montpellier.inra.fr/CBGP/acarologia/ acarologia@supagro.inra.fr

\section{OPEN ACCESS}

\section{Acarologia is proudly non-profit, with no page charges and free open access}

Please help us maintain this system by encouraging your institutes to subscribe to the print version of the journal and by sending us your high quality research on the Acari.

Subscriptions: Year 2017 (Volume 57): $380 €$ http://www1.montpellier.inra.fr/CBGP/acarologia/subscribe.php

Previous volumes (2010-2015): $250 € /$ year (4 issues)

Acarologia, CBGP, CS 30016, 34988 MONTFERRIER-sur-LEZ Cedex, France

The digitalization of Acarologia papers prior to 2000 was supported by Agropolis Fondation under the reference ID 1500-024 through the « Investissements d'avenir » programme

(Labex Agro: ANR-10-LABX-0001-01)
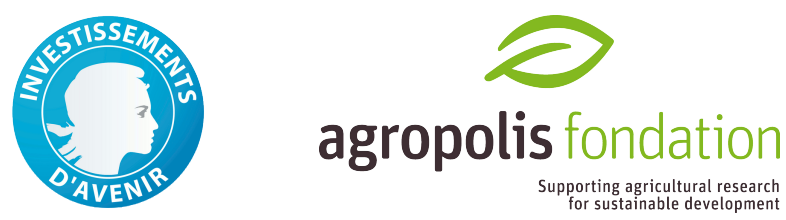

Acarologia is under free license and distributed under the terms of the

Creative Commons-BY-NC-ND which permits unrestricted non-commercial use, distribution, and reproduction in any medium, provided the original author and source are credited. 


\title{
A NEW SPECIES OF LARVAL LEPTUS (PARASITENGONA: ERYTHRAEIDAE) AND NEW RECORDS OF LARVAL ERYTHRAEIDAE PARASITIZING ORTHOPTERA FROM FRENCH GUIANA
}

\author{
Jaime G. MAYORAL ${ }^{1, *}$ and Pablo BARRANCO ${ }^{2}$ \\ (Received 26 August 2011; accepted 13 December 2011; published online 20 December 2011) \\ ${ }^{1}$ Department of Biological Sciences. Florida International University, Miami, FL, USA. jgmayoral@hotmail.com ( *Corresponding author) \\ ${ }^{2}$ Dpto. Biología Aplicada. CITE II-B. Universidad de Almería, 04120, Almería, Spain. pbvega@ual.es
}

\begin{abstract}
A total of 30 larval mites (Erythraeidae) parasitizing 8 species of Orthoptera were captured during a sampling trip in French Guiana. These collections represent the first reports for the genera Leptus and Charletonia from this country. It is the first time that Leptus nikanori Haitlinger, 2000 has been captured outside of Costa Rica and the third record for Charletonia domawiti Haitlinger, 2004 after being reported from Brazil and Costa Rica. We also describe and illustrate the new species Leptus multisolenidiae parasitizing Episomacris gruneri (Descamps and Amédégnato 1970).
\end{abstract}

KEYWORDS - French Guiana; Erythraeidae; Charletonia domawiti; Leptus multisolenidiae n. sp.; Leptus nikanori

\section{INTRODUCTION}

During a field trip in French Guiana, we collected 30 larval erythraeid mites parasitizing 8 species of Orthoptera. The mites captured belong to the Family Erythraeidae Robineau-Desvoidy 1828. Two of the species identified belong to the genus Leptus Latreille 1796 and another species belongs to the genus Charletonia Oudemans 1910. Both genera are distributed world-wide but no captures have been reported previously from French Guiana.

Haitlinger (2004a) reported 19 species of Leptus described from South America. Since then, only one species Leptus tiranicus Haitlinger 2006 from Isla Margarita (Venezuela) has been described (Haitlinger 2006). The genus Charletonia is less known and only 8 species have been reported from the New World, two from Central America, two from South America and 4 from North America (Treat and Flechtmann 1979; Southcott 1991; Haitlinger 2000a; Haitlinger 2004b; Mayoral and Barranco 2011).

\section{MATERIALS AND METHODS}

Mites parasitizing different species of orthopterans were removed from their hosts under a binocular microscope using with forceps. Orthopterans were captured during a sampling field trip in French Guiana by hand or using light traps. Measurements and illustrations were made after clearing the specimens in $50 \%$ lactic acid and mounting them on slides using PVA medium (Walter and Krantz 2009) using a Nikon Optiphot-2 compound microscope with a drawing attachment. All the measurements are given in micrometers. Terminology and abbre- 
Mayoral J.G. and Barranco P.
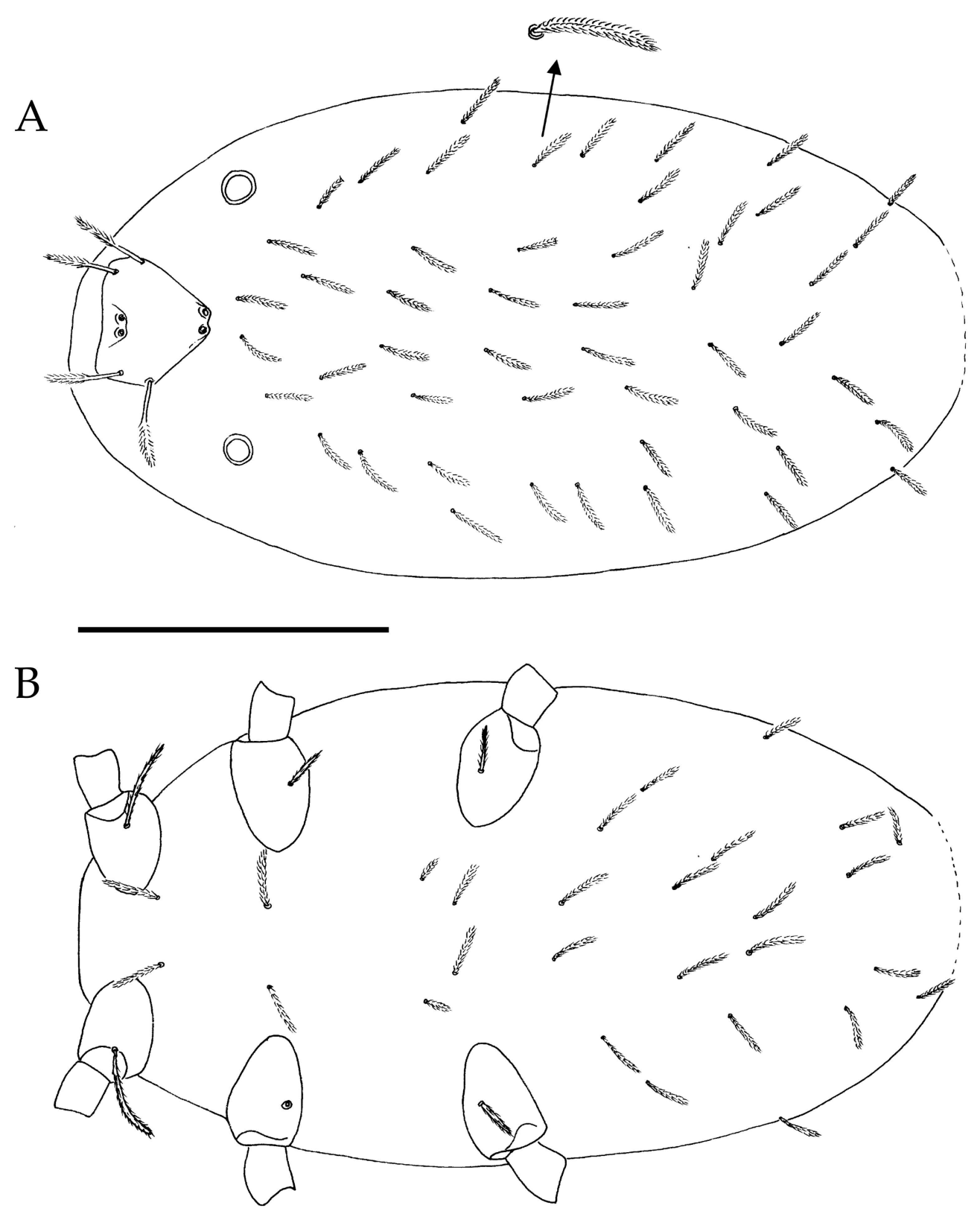

FIGURE 1: Leptus multisolenidiae n. sp. (larvae), holotype. A - idiosoma, dorsal view; B - idiosoma, ventral view. Scale bar $100 \mu \mathrm{m}$. 
viations for the description of the new species follows Southcott (1993) and Haitlinger (1999). Data on paratype are written in parentheses.

\section{RESULTS}

\section{Family Erythraeidae Robineau-Desvoidy 1828}

\section{Genus Charletonia Oudemans 1910}

Charletonia domawiti Haitlinger 2004

Material studied - 1 larva, Kaw mountain. Cayenne. French Guiana. 8-1-2008. P. Barranco leg. On Romaleidae (R-290); 4 larvae, Kaw mountain. Cayenne. French Guiana. 8-1-2008. P. Barranco leg. On Schistocerca nitens (Thunberg 1815) P. Barranco det. (R-291A-D); 9 larvae, Kaw mountain. Cayenne. French Guiana. 8-1-2008. P. Barranco leg. On Abracris flavolineata (De Geer 1773) P. Barranco det. (R-293A-I).

Remarks - This species was described from Brazil (Haitlinger 2004b) and captured on plants from a single specimen. Mayoral and Barranco (2011) captured this species in Costa Rica parasitizing Neoconocephalus triops Linnaeus 1758 (Tettigoniidae, Conocephallinae). Now, we report $C$. domawiti from French Guiana parasitizing two species of Acrididae (Orthoptera). This is the third report of this species worldwide. The hosts known for this species are all different species of Orthoptera. However, this species is able to parasitize the two different suborders, the long-horned (Ensifera) and the short-horned Orthoptera (Caelifera).

\section{Genus Leptus Latreille 1796}

Leptus nikanori Haitlinger 2000

Material studied -2 larvae, Kaw mountain. 8-12008. French Guiana. P. Barranco leg. On Pseudoproscopia scabra (Klug 1820) P. Barranco det. (R282A-B); 6 larvae, Kaw mountain. 8-I-2008. Roura. French Guiana. P. Barranco leg. On Ommatotalpinae (R-283A-F); 2 larvae, Kaw mountain. 121-2008. Roura. French Guiana. P. Barranco leg. On Ommatotalpinae (R-284A-B); 4 larvae, Kaw mountain. 8-1-2008. Roura. French Guiana. P. Barranco leg. On Anaulacomera sp. (R-285A-D).
Remarks - Leptus nikanori was described from a single specimen from Irazú, Costa Rica collected on plants (Haitlinger 2000b). Later, it was captured parasitizing 3 species of katydids and 2 species of phasmids, also in Costa Rica (Mayoral and Barranco 2011). For the first time this species is captured in French Guiana.

The morphometric data and chaetotaxia of these specimens are identical to the ones reported from Costa Rica (Mayoral and Barranco 2010). Interestingly, some specimens from French Guiana show a longer solenidia on tarsus I (72- $94 \mu \mathrm{m})(\mathrm{R}-282 \mathrm{~A}, \mathrm{~B}$; R-283A-F; R-284A,B) while other specimens captured in a location nearby have shorter solenidia $(45-49 \mu \mathrm{m})(\mathrm{R}-285 \mathrm{~A}-\mathrm{D})$. The second ones have the same length ("short") as the ones reported from Costa Rica in Mayoral and Barranco (2011).

\section{Leptus multisolenidiae $\mathbf{n} . \mathbf{s p}$. \\ (Figures 1-3; Table 1)}

Material studied - Holotype, larva, Kaw mountain. Cayenne. French Guiana. 8-1-2008. P. Barranco leg. On Episomacris gruneri (Descamps and Amédégnato 1970) P. Barranco det. (R-292B); Paratype, 1 larva, same location, collector and host as holotype (R-292A). Holotype and paratype are deposited in the "Museo Nacional de Ciencias Naturales de Madrid" (MNCN) in Spain with numbers MNCN 20.02/17155 and MNCN 20.02/17156, respectively.

Description based on holotype - Color in life red-orange. Idiosoma oval (holotype slightly engorged), length $337 \mu \mathrm{m}$ and width $187 \mu \mathrm{m}$. Dorsum of idiosoma with 49 (47) setae in irregular transverse rows, $45-50 \mu \mathrm{m}$ long (Figure 1A). Dorsal scutum moderately chitinized, porose but without striations, triangular shaped. Two pairs of filliform sensilla, posteriors (S) twice longer than the anteriors ones (AM) (Table 1); both with fine setules in distal $1 / 5$ and $1 / 3$ of their entire length, respectively. Scutum bearing two pair of scutalae (AL and PL), similar in length (Figure 2A); AL setae are nude in proximal $1 / 2$ of its entire length and PL are nude in proximal $1 / 3$.

Ventral idiosoma with one coxala on coxae I, II and III, coxala I the longest (Table 1). Two inter- 
A



FIGURE 2: Leptus multisolenidiae n. sp. (larvae), paratype. A - scutum; B - gnathosoma, right side dorsal view; left side ventral view. Scale bar $60 \mu \mathrm{m}$. 


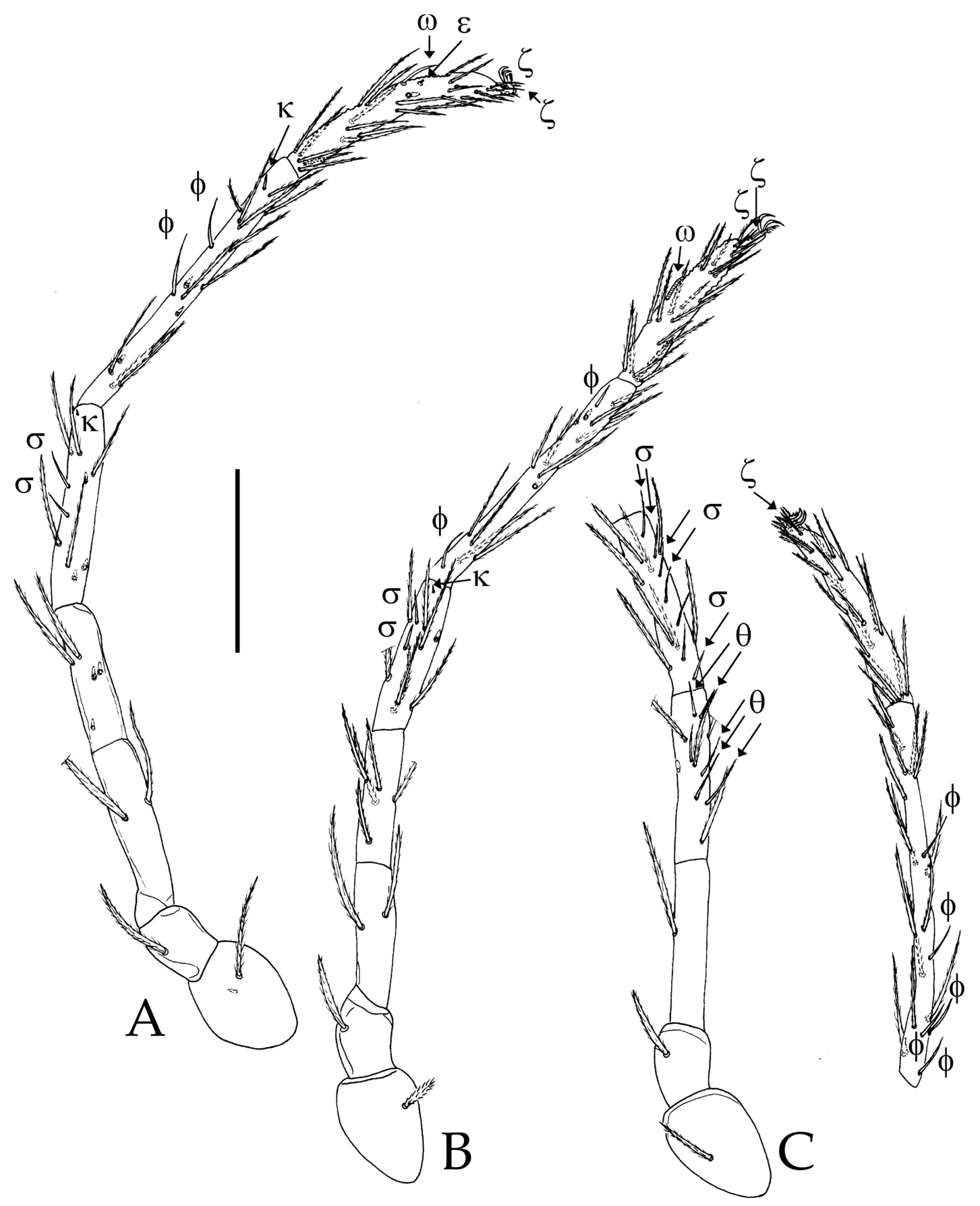

FIGURE 3: Leptus multisolenidiae n. sp. (larvae), paratype. A - Leg I; B - Leg II; C - Leg III. Scale bar 150 m. 
coxalae between coxae I, $54 \mu \mathrm{m}$ long, two between coxae II, $50 \mu \mathrm{m}$ long and 4 intercoxalae between coxae II-III, the anterior ones shorter $(27 \mu \mathrm{m})$ than the posterior ones $(45 \mu \mathrm{m})$. Behind coxae III, 20 (19) setae with setules, $41-50 \mu \mathrm{m}$ (Figure 1B).

Gnathosoma porose, narrow, length $247 \mu \mathrm{m}$. One pair of galealae with small setules, pointed, $22 \mu \mathrm{m}$ long; anterior hypostomala smooth, pointed, simple, $13 \mu \mathrm{m}$ long; posterior hypostomala with similar shape but thicker and stronger, with fine setules, 54 $\mu \mathrm{m}$ long; palpal supracoxala present, blunted peg, $4 \mu \mathrm{m}$ long. Palpal setal formula: $\mathrm{fPp}=0-\mathrm{B}-\mathrm{B}-\mathrm{BBB}-$ 3B3N (Figure 2B).
Leg setal formula: Leg I: Ta-1,2,1,25B; Ti-2,1,14B; Ge-2,1,8B; Tf-5B; Bf-2B; Tr-1B, Cx-1B (Figure 3A). Leg II: Ta-1,2,24B; Ti-2,15B; Ge-2 (2-3),1,8B; Tf-5B; Bf-2B; Tr-1B, Cx-1B (Figure 3B). Leg III: Ta-1,24B; Ti5-6,15B; Ge-7-9 (8),8B; Tf-6-7, 5B; Bf-1B; Tr-1B, Cx-1B (Figure 3C).

$\mathrm{IP}=1041+940+1116=3097$ (Holotype)

$\mathrm{IP}=946+851+1016=2813$ (Paratype)

Measurements for the holotype and paratype are given in Table 1.

Remarks - The presence of multiple solenoidialae on the genua III can be found only in one species of the genus Leptus, L. comosus Southcott,

TABLE 1: Morphometric data (in micrometers) for Leptus multisolenidiae n. sp. (larvae) from French Guiana.

\begin{tabular}{cccccc}
\hline Character & Holotype & Paratype & Character & Holotype & Paratype \\
\hline IL & 270 & 337 & Bf I & 135 & 119 \\
IW & 150 & 187 & Tf I & 128 & 117 \\
L & 120 & 112 & Ge I & 171 & 150 \\
W & 130 & 119 & Ti I & 265 & 230 \\
AW & 92 & 92 & Ta I & 189 & 186 \\
PW & 115 & 112 & Cx II & 110 & 108 \\
AA & 12 & 13 & Tr II & 72 & 63 \\
SB & 16 & 16 & Bf II & 117 & 103 \\
ISD & 79 & 75 & Tf II & 110 & 108 \\
AP & 27 & 29 & Ge II & 135 & 117 \\
AL & 81 & 74 & Ti II & 230 & 202 \\
PL & 88 & 77 & Ta II & 166 & 150 \\
AM & 51 & - & Cx III & 112 & 106 \\
S & 108 & - & Tr III & 68 & 63 \\
DS & $47-54$ & $45-50$ & Bf III & 137 & 121 \\
GL & 243 & 247 & Tf III & 139 & 135 \\
$\mathbf{1} b$ & 90 & 87 & Ge III & 155 & 135 \\
$\mathbf{2} \boldsymbol{b}$ & 36 & 31 & Ti III & 321 & 285 \\
$\mathbf{3 b}$ & 52 & 48 & Ta III & 184 & 171 \\
$\mathbf{C x}$ I & 95 & 86 & IP & 3097 & 2813 \\
Tr I & 58 & 58 & & & \\
\hline
\end{tabular}


1991 from South Australia with six solenoidialae (Southcott 1991). Leptus multisolenidiae n. sp. has $7-9$ solenidiae on Ge III and therefore belongs to this exclusive group of species. Leptus comosus is also the only species with solenoidalae on Tf I, II, III bearing 3, 4, 6-7, respectively. Leptus multisolenidiae $\mathbf{n}$. sp. carries $6-7$ solenoidalae on telofemur III (same as L. comosus), but has none on Tf I or II.

However, these two species differ from each other in several characters. Leptus comosus belongs to the group of Leptus with two genualae on the palp and is characterized as being "an extremely hairy larva, more so than any other described species" (Southcott 1991b), bearing ventrally more than 80 setae anterior to coxae III. This is not the case for L. multisolenidiae that belongs to the group of Leptus with one genuala on the palp and carries only 8 setae anterior to coxae III. Morphometric data also allows us to differentiate both species well, all the segments of the legs are considerably longer in the new species, $c f$. the length of the Ti I, II, III (230 275, $202-230,285-321$ vs. $118-138,108-125$, 158 - 186); thus resulting in a much larger IP (2813 - 3097 vs. 1820, respectively).

Etymology - The name of the species is after the presence of many solenidiae on the telofemur of the leg III.

\section{ACKNOWLEDGEMENTS}

We would like to thank Mario Perez for the revision of the manuscript.

\section{REFERENCES}

Haitlinger R. 1999 - Six new species of Leptus Latreille 1796 (Acari, Prostigmata, Erythraeidae) from SouthEast Asia - Miscellania Zoologica, 22: 51-68.

Haitlinger R. 2000a - New larval mites (Acari: Prostigmata: Erythraeidae, Microtrombidiidae, Trombidiidae) from Turkey, Peru and Poland - Wiad. Parazyt., 46: 379-396.

Haitlinger R. 2000b - Four new species of Leptus Latreille 1796 (Acari: Prostigmata: Erythraeidae) from Central America - Syst. Appl. Acarol., 5: 131-142.

Haitlinger R. 2004a - Three new species of Leptus Latreille 1796 and the first record of Leptus onnae
Haitlinger 2000 (Acari: Prostigmata: Erythraeidae) from Brazil — Syst. Appl. Acarol., 9: 147-156.

Haitlinger R. 2004b - Charletonia domawiti n. sp., Caeculisoma nestori $\mathbf{n}$. sp., and Iguatonia barbillae $\mathrm{n}$. gen. and n. sp. from Brazil (Acari: Prostigmata: Erythraeidae) - Genus, 15: 435-444.

Haitlinger R. 2006 - Dasitrombium margeritanum n. sp., Leptus tiranicus n. sp. and the first record of L. olafi Haitlinger (Acari: Prostigmata: Neothrombiidae, Erythraeidae) ectoparasitic on Orthoptera and Diptera (Insecta) from Margerita, Venezuela - Polskie Pismo Entomologiczne, 75: 347-357.

Haitlinger R. 2009 - New records of mites (Acari: Prostigmata: Erythraedidae) from Nepal, with a description of Leptus (Leptus) kattikus n. sp. - Syst. Appl. Acarol., 14: 60-64.

Mayoral J.G., Barranco P. 2011 - A new species of larval Charletonia (Parasitengona: Erythraeidae) and new records of larval Erythraeidae parasitizing Orthoptera and Phasmida from Costa Rica - Acarologia, 51: 219227.

Southcott R.V. 1991a - A further revision of Charletonia (Acarina: Erythraeidae) based on larvae, protonymphs and deutonymphs - Invertebr. Taxon., 5: 61-131. doi:10.1071/IT9910061

Southcott R.V. 1991b - Description of larval Leptus (Acarina: Erythraeidae) ectoparasitic on Australian Diptera, and two earlier described Australian larvae - Invertebr. Taxon., 5: 717-763. doi:10.1071/IT9910717

Southcott R.V. 1993 - Larvae of Leptus (Acarina: Erythraeidae) ectoparasitic on higher insects of Australia and New Guinea - Invertebr. Taxon., 7: 1473-1550. doi:10.1071/IT9931473

Treat A., Flechtmann C.H.W. 1979 - Charletonia rocciai, $\mathbf{n}$. sp. (Acari, Prostigmata, Erythraeidae), an ectoparasite of the Amazon fly - Internat. J. Acarol., 5: 117-122. doi:10.1080/01647957908683134

Walter D.E., Krantz G.W. 2009 - Collecting, rearing, and preparing specimens - In: Krantz G.W., Walter D.E. (Eds). A manual of Acarology. Third edition - Texas Tech University Press, Lubbock, Texas. USA. p. 83-96.

\section{COPYRIGHT}

$((c)$ EY-No-ND Mayoral and Barranco. Acarologia is under free license. This open-access article is distributed under the terms of the Creative Commons-BY-NC-ND which permits unrestricted non-commercial use, distribution, and reproduction in any medium, provided the original author and source are credited. 